\title{
RAC to finally relax gene therapy oversight
}

The 40-year old Recombinant DNA Advisory Committee (RAC) is set to ease its oversight over gene therapy research, providing a welcome relief to US academics and companies working in the field. "Everyone is happy," says Barry Byrne, director of the University of Florida Powell Gene Therapy Center and chair of the Clinical Trials and Regulatory Affairs Committee at the American Society of Gene \& Cell Therapy.

The National Institutes of Health (NIH) established the RAC in 1974 to review gene therapy research protocols when the approach was new, but over the years the committee's intervention has come to be seen as an unnecessary and burdensome process, creating piles of paperwork and sometimes delaying clinical trial initiation. Gene therapy technology has been de-risked, say the RAC's critics, adding that the US Food and Drug Administration, and institutional review boards and institutional biosafety boards now provide sufficient levels of oversight. "In some cases there were discordant opinions from the various review bodies, and investigators could feel like they were in a tennis match, going back and forth trying

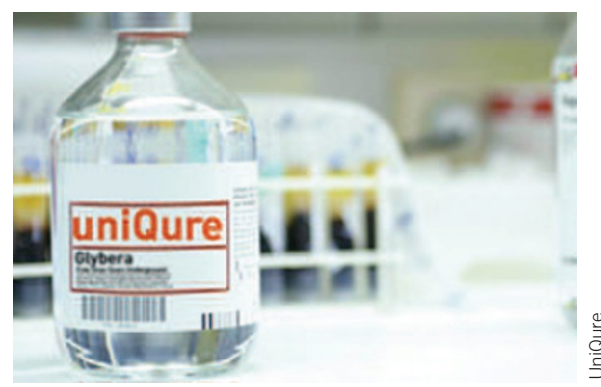

Last summer's approval for uniQure's gene therapy Glybera might have shifted stiff regulatory headwinds. to address the critiques that they received," says Byrne.

The Institute of Medicine (IOM) looked into the perceived redundancy at the behest of the NIH, and reported last December that the 21-expert RAC is ready for an overhaul (http://www.iom.edu/Reports/2013/Oversightand-Review-of-Clinical-Gene-TransferProtocols/Report-Brief120513.aspx). "Not all of gene transfer research is novel enough or controversial enough to justify all the current forms of additional oversight," they wrote. RAC reviews should be scaled down, they concluded, required only for "exceptional circumstance" research protocols, such as when new vectors or new preclinical models are used or when uncommon toxicities are expected.

The NIH announced in May that it will heed the IOM's recommendations, and is developing a streamlined RAC review process that will reduce administrative duplication and delays. Changes to the NIH guidelines will be posted in the near future on the Federal Register, giving the public an opportunity to comment, wrote NIH spokeswoman Renate Myles in an email to Nature Biotechnology.

The RAC is being downsized even as the gene therapy field is undergoing a renaissance. "There certainly has been a surge in the belief that this technology can be commercialized," says Byrne. He points to at least five new gene therapy companies that have been launched in the past eight months, and over \$500 million in early-stage funding that has boosted the field. Interest is no longer limited to small biotechs, he adds. Baxter, Bayer, GlaxoSmithKline and other large pharmas are also dipping their toes into gene therapy waters. "It may be evidence that there is an improving regulatory environment," says Byrne, "but it might also be a coincidence." Strong preclinical data and viable market opportunities might also fueling growing enthusiasm, he explains.

"The excitement and the noise out there is tremendous," agrees Robert Pietrusko, senior vice president of regulatory affairs at Cambridge, Massachusetts-based Voyager Therapeutics, a recently launched gene therapy company, which focuses on the central nervous system.

Regulatory agencies on both sides of the Atlantic have also clarified certain aspects of gene therapy development. In June, the US Food and Drug Administration published a draft guidance on the need for environmental assessments for gene therapies (http://www. fda.gov/downloads/BiologicsBloodVaccines/ GuidanceComplianceRegulatoryInformation/ Guidances/CellularandGeneTherapy/ UCM402063.pdf). In July, it published draft guidance on when and how sponsors should study whether potentially transmissible viruses and bacteria used in gene therapies are shed by treated patients through feces, urine, saliva or other means (http:// www.fda.gov/BiologicsBloodVaccines/ GuidanceComplianceRegulatoryInformation/ Guidances/CellularandGeneTherapy/ ucm404050.htm).

"[US regulators] are preparing the groundwork for a gene therapy approval," says Pietrusko. "It is just a matter of time before the first gene therapy is approved [in the US]." The first gene therapy-Amsterdam-based uniQure's Glybera (alipogene tiparvovec) —-was approved in Europe in 2012 (Nat. Biotechnol. 30, 1153, 2012). In June, the European Medicines Agency published a draft reflection paper that, among other things, clarified exactly what it considers to be gene therapy products (http:// www.ema.europa.eu/docs/en_GB/document_library/Scientific_guideline/2014/06/ WC500169466.pdf).

Asher Mullard Ottawa, Ontario 